\title{
The human intervertebral disc as a source of DNA for molecular identification
}

\author{
Julia Becker ${ }^{1} \cdot$ Nina Sophia Mahlke $^{1} \cdot$ Stefanie Ritz-Timme ${ }^{1} \cdot$ Petra Boehme $^{1}$
}

Accepted: 8 June 2021 / Published online: 22 July 2021

(c) The Author(s) 2021

\begin{abstract}
Genetic analyses such as STR-typing are routinely used for identification purposes in forensic casework. Although genotyping techniques only require a minimum amount of DNA to provide a genetic profile, DNA quality differs not only between but also within tissues during ongoing decomposition. Initiated by a recent case where, due to the constitution of the body, preferred tissue was not available or only resulted in a partial and not usable DNA profile, the analysis of intervertebral discs as a source of DNA was considered. As the analysis of this tissue resulted in a high quality DNA profile a further study was performed in which thirty intervertebral discs dissected from bodies in different stages of decay were analyzed. All samples yielded good quality DNA in quantities suitable for STR-based amplification with no or only low degradation indices, resulting in complete genetic profiles. These results demonstrate the robustness of human intervertebral disc tissue as a source of DNA for molecular identification purposes.
\end{abstract}

Keywords Short tandem repeats $\cdot$ Molecular identification $\cdot$ Intervertebral disc $\cdot$ Decomposition

\section{Introduction}

STR-based DNA profiling has become the gold standard for identification purposes, especially for highly decomposed bodies or body fragments [1-3]. Fortunately, all human tissue contains cell nuclei and very small amounts can be used for DNA extraction [4-9]. However, high quality DNA is typically restricted to fresh tissue samples. Decomposition processes and/or environmental factors reduce the stability and integrity of DNA within and between tissues [10-12]. Thus, for bodies in advanced stages of putrefaction, when suitable samples of organs and muscles may no be longer available, solid material such as teeth or bones have to be used for analysis [13, 14]. However, processing may be timeconsuming and/or technically difficult and may depend on experience $[15,16]$. Cartilages and ligaments, like the Achilles tendon, are quite resistant to autolysis and putrefaction and thus well suited for molecular identification even in heavily decomposed bodies [17-21]. When preferred tissue is not available or is too degraded to generate complete

Julia Becker

Julia.Becker@med.uni-duesseldorf.de

1 Institute of Legal Medicine, University Hospital Düsseldorf, Moorenstraße 5, 40225 Düsseldorf, Germany genetic profiles, the analysis of intervertebral discs (IVDs) may be considered. IVDs are composed of two main components, namely the annulus fibrosus that consists of concentric fibrous layers and the gelatinous centralized nucleus pulposus. In general, the extracellular matrix of the IVD is comprised of collagen, elastin and other non-collagenous components [22]. The cells are embedded in the matrix and due to the absence of blood vessels, the matrix may serve as a physical barrier that reduces the tissue's susceptibility to degradation processes. The present study does not intend to demonstrate that IVDs are more suitable than other material but to show that they can be considered as a good source of DNA for molecular identification.

\section{Material and methods}

\section{Sample collection}

Intervertebral discs were collected from 30 bodies ( 23 males, 7 females; 24 to 87 years old) during autopsy at the Institute of Forensic Medicine Düsseldorf, Germany (Table 1). Twenty-three bodies were in different stages of decay (fresh to advanced/skeletonized; defined by forensic pathologists based on morphological characteristics as described by 
Table 1 Samples from bodies in different stages of decay. State of decay according to Megyesi [23] for the entire body, appearance of the IVDs postmortem intervals (as far as known), DNA concentration (in $\mathrm{ng} / \mu \mathrm{l}$ ) and degradation indices (both with standard deviation) measured in duplicates for each sample. $\mathrm{m}=$ male, $\mathrm{f}=$ female, age in years. Asterisk $(*)=$ bodies with a partially skeletonized torso; black circle $(\bullet)=$ body where only IVD between the lumbar vertebral bodies 4 and 5 could be collected; A-D =STR profile (blue dye channel) shown in Fig. 1

\begin{tabular}{|c|c|c|c|c|c|}
\hline Age and sex & Stage of decomposition & $\begin{array}{l}\text { Appearance of interver- } \\
\text { tebral discs }\end{array}$ & Postmortem interval & DNA concentration & Degradation index \\
\hline $36, \mathrm{~m}^{\mathrm{A}}$ & Fresh & No abnormalities & $<3$ days & $34.02 \pm 0.92$ & $1.11 \pm 0.02$ \\
\hline $68, \mathrm{~m}$ & Fresh & No abnormalities & $<3$ days & $32.23 \pm 1.16$ & $1.15 \pm 0.05$ \\
\hline $50, \mathrm{~m}$ & Fresh & No abnormalities & $<3$ days & $14.42 \pm 0.52$ & $1.13 \pm 0.01$ \\
\hline $87, \mathrm{f}$ & Fresh & No abnormalities & $<3$ days & $39.71 \pm 0.79$ & $2.62 \pm 0.06$ \\
\hline $28, \mathrm{~m}$ & Fresh & No abnormalities & $<3$ days & $5.28 \pm 0.44$ & $1.68 \pm 0.03$ \\
\hline $46, \mathrm{~m}$ & Fresh & No abnormalities & $<3$ days & $13.89 \pm 0.02$ & $1.24 \pm 0.05$ \\
\hline \multirow[t]{2}{*}{$70, \mathrm{f}$} & Fresh & No abnormalities & $<3$ days & $4.64 \pm 0.18$ & $1.06 \pm 0.02$ \\
\hline & & & Mean & $20.74 \pm 13.87$ & $1.42 \pm 0.54$ \\
\hline $39, \mathrm{~m}$ & Early & No abnormalities & unknown & $8.40 \pm 1.09$ & $1.20 \pm 0.01$ \\
\hline $24, \mathrm{~m}$ & Early & No abnormalities & unknown & $19.63 \pm 0.00$ & $1.41 \pm 0.02$ \\
\hline $28, \mathrm{~m}$ & Early & No abnormalities & unknown & $14.93 \pm 2.50$ & $1.38 \pm 0.02$ \\
\hline $64, \mathrm{~m}$ & Early & No abnormalities & $<14$ days & $24.24 \pm 0.00$ & $2.80 \pm 0.07$ \\
\hline $47, \mathrm{~m}$ & Early & No abnormalities & approx. 4 days & $3.67 \pm 0.42$ & $1.39 \pm 0.02$ \\
\hline $70, \mathrm{f}$ & Early & Brown discoloration & $<7$ days & $20.03 \pm 0.00$ & $1.63 \pm 0.04$ \\
\hline $65, \mathrm{~m}$ & Early & Brown discoloration & $<10$ days & $11.45 \pm 1.96$ & $1.37 \pm 0.01$ \\
\hline $52, \mathrm{~m}$ & Early & Brown discoloration & unknown & $1.51 \pm 0.09$ & $1.29 \pm 0.06$ \\
\hline $61, \mathrm{f}$ & Early & Green discoloration & unknown & $5.50 \pm 0.52$ & $4.46 \pm 0.26$ \\
\hline \multirow[t]{2}{*}{$61, \mathrm{~m}$} & Early & Green discoloration & unknown & $13.10 \pm 0.05$ & $1.29 \pm 0.02$ \\
\hline & & & Mean & $13.19 \pm 7.12$ & $1.59 \pm 0.48$ \\
\hline $60, \mathrm{~m}$ & Advanced & No abnormalities & unknown & $3.74 \pm 0.26$ & $1.64 \pm 0.07$ \\
\hline $31, \mathrm{~m}$ & Advanced & Brown discoloration & unknown & $12.00 \pm 0.04$ & $1.45 \pm 0.09$ \\
\hline $66, f$ & Advanced & Brown discoloration & unknown & $4,57 \pm 0.18$ & $1.47 \pm 0.02$ \\
\hline $45, \mathrm{~m}$ & Advanced* & Brown discoloration & unknown & $4.04 \pm 0.14$ & $1.50 \pm 0.02$ \\
\hline $47, \mathrm{~m}$ & Advanced & Brown discoloration & $<21$ days & $16.05 \pm 0.83$ & $2.02 \pm 0.13$ \\
\hline \multirow[t]{3}{*}{$65, \mathrm{~m} \bullet^{\mathrm{B}}$} & Advanced* & Brown discoloration & 21-28 days & $11.41 \pm 0.98$ & $1.92 \pm 0.03$ \\
\hline & & & Mean & $7.06 \pm 3.93$ & $2.05 \pm 1.15$ \\
\hline & Others & & & & \\
\hline $79, \mathrm{~m}$ & Exhumed & No abnormalities & approx. 2 months & $70.20 \pm 0.00$ & $1.67 \pm 0.07$ \\
\hline $83, \mathrm{~m}$ & Exhumed & No abnormalities & approx. 2 months & $13.51 \pm 0.05$ & $1.52 \pm 0.05$ \\
\hline $84, \mathrm{~m}$ & Exhumed & No abnormalities & approx. 2 months & $5.31 \pm 0.58$ & $1.48 \pm 0.04$ \\
\hline $48, \mathrm{~m}^{\mathrm{D}}$ & Severe burns & No abnormalities & $<1$ day & $15.11 \pm 0.30$ & $1.41 \pm 0.03$ \\
\hline $58, \mathrm{f}$ & Severe burns & No abnormalities & $<1$ day & $14.12 \pm 0.21$ & $1.12 \pm 0.00$ \\
\hline $58, \mathrm{~m}$ & Most severe burns & No abnormalities & $<1$ day & $3.13 \pm 0.24$ & $1.11 \pm 0.01$ \\
\hline $57, \mathrm{f}^{\mathrm{C}}$ & Drowned & No abnormalities & approx. 1 month & $11.40 \pm 0.00$ & $1.53 \pm 0.04$ \\
\hline
\end{tabular}

Megyesi et al. [23]) and seven bodies were either exhumed, burnt or drowned. IVDs were dissected between the lumbar vertebral bodies 2 and 3 of the spinal column. One body, however, was in such an advanced stage of decomposition that due to partial skeletonization and exposed limbs only the IVD between the lumbar vertebral bodies 4 and 5 could be collected. The postmortem interval, if known, ranged between 1 to 28 days. All tissue samples were stored at $-80{ }^{\circ} \mathrm{C}$ until further processing.

\section{DNA extraction}

Prior to DNA extraction, ligament residues were removed from the IVDs using a sterile scalpel. Subsequently, an approximately $3 \times 2 \mathrm{~mm}$ piece was cut out of the outer layers of the anterior annulus fibrosus for DNA extraction using a silica-based method (NucleoSpin ${ }^{\circledR}$ Tissue Kit from Macherey-Nagel, Düren, Germany). The extraction was performed according to the manufacturer's instruction with 
overnight at $56{ }^{\circ} \mathrm{C}$ in a shaking thermal block (ThermoMixer® C, Eppendorf). DNA was eluted in $50 \mu \mathrm{l}$ BE buffer (included in Macherey-Nagel kit). DNA extracts were stored at $-20{ }^{\circ} \mathrm{C}$.

\section{Quantification and amplification}

Quantitation was performed in duplicates using the Applied Biosystems $^{\text {TM }} 7500$ Real-Time PCR System and the Quantiplex ${ }^{\circledR}$ Pro Kit (Qiagen) following manufacturer's instructions with default settings. A multiplex PCR for 17 STR loci (PowerPlex® ESI 17 Fast System, Promega) was performed in a total reaction volume of $12.5 \mu \mathrm{l}$. Where possible an optimum of 0.5 ng template DNA was added to the PCR reaction. Thermal cycling conditions were followed as described by the manufacturer. Capillary electrophoretic separation was performed on the ABI Prism ${ }^{\circledR}$ Genetic Analyzer 3130 equipped with a $36 \mathrm{~cm}$ Capillary Array/POP-4 (Applied Biosystems, Darmstadt, Germany) following manufacturer's instructions. Data acquisition and analysis was performed using the ABI Prism 3130 Collection software (Applied Biosystems, Darmstadt, Germany) and GeneMapperID ${ }^{\circledR}$ v.3.2 software (Applied Biosystems, Darmstadt, Germany).

\section{Results}

\section{Morphological features of the intervertebral discs}

Because a standardized removal of IVDs turned out to be challenging due to degenerative changes and/or the positioning of the spine, the appearance of the dissected IVDs differed. In most cases, it was possible to dissect the complete IVD, in some cases only the anterior part or even fragments could be removed. Ten intervertebral discs of bodies that were in an advanced stage of putrefaction showed slight discolorations (green to brown) (Table 1). The remaining samples showed no noteworthy discolorations.

\section{Quantification analysis}

Quantitation yielded sufficient amounts of DNA for further STR-analysis in all samples (Table 1). Quantity, however, was very variable between samples and ranged from 1.51 to $70.2 \mathrm{ng} / \mu \mathrm{l}$ with standard deviations between 0.02 to $2.50 \mathrm{ng} / \mu \mathrm{l}$. The amount of extracted DNA was significantly higher for IVDs collected from fresh bodies (mean value: $20.60 \mathrm{ng} / \mu \mathrm{l} \pm 14.45 \mathrm{ng} / \mu \mathrm{l}$ ) than for IVDs from bodies in an initial to advanced stage of decay $(10.89 \mathrm{ng} / \mu \mathrm{l} \pm 6.84 \mathrm{ng} / \mu \mathrm{l}$ ) with a $\mathrm{p}$-value of 0.0165 (two tailed Welch t-test with $\alpha=0.05$ ). Detailed information about quantity and quality is summarized in Table 1 for each stage of decomposition.

\section{DNA profile quality}

Although variation in quantity was observed, there was no measurable inhibition or noteworthy degradation (degradation indices between 1.06 and 4.46; kit-specific threshold with a default setting index of 10) in any of the 30 IVD samples and STR-analysis resulted in full and single-source DNA profiles with no artefacts (Fig. 1).

\section{Discussion}

The inverse relationship between the degree of decomposition and quantity of extracted DNA may be explained by an increasing DNA degradation in terms of fragmentation with increasing degree of putrefaction [24-26]. This relationship was also observed in an in vitro study in which IVDs putrefied under controlled conditions (dry and wet) for several days to simulate longer postmortem intervals (data not shown). Interestingly, neovascularization, i.e. the formation of new blood vessels, may occur in IVDs $[27,28]$ and thus, decay-induced microorganisms may have easier access, which may accelerate the breakdown of tissue. A variation between samples (within one stage of decay) may be due to the distribution of cells (e.g. clusters, single cells) [29, 30], a varying thickness (i.e. height) of the removed IVDs, or differences in bacterial colonization [31]. However, morphological appearance, i.e. discoloration is not related to quantity and/or quality of extracted DNA. According to our data, human intervertebral disc tissue is very resistant against degradation processes and may be considered as source of DNA for STR-based identification. 

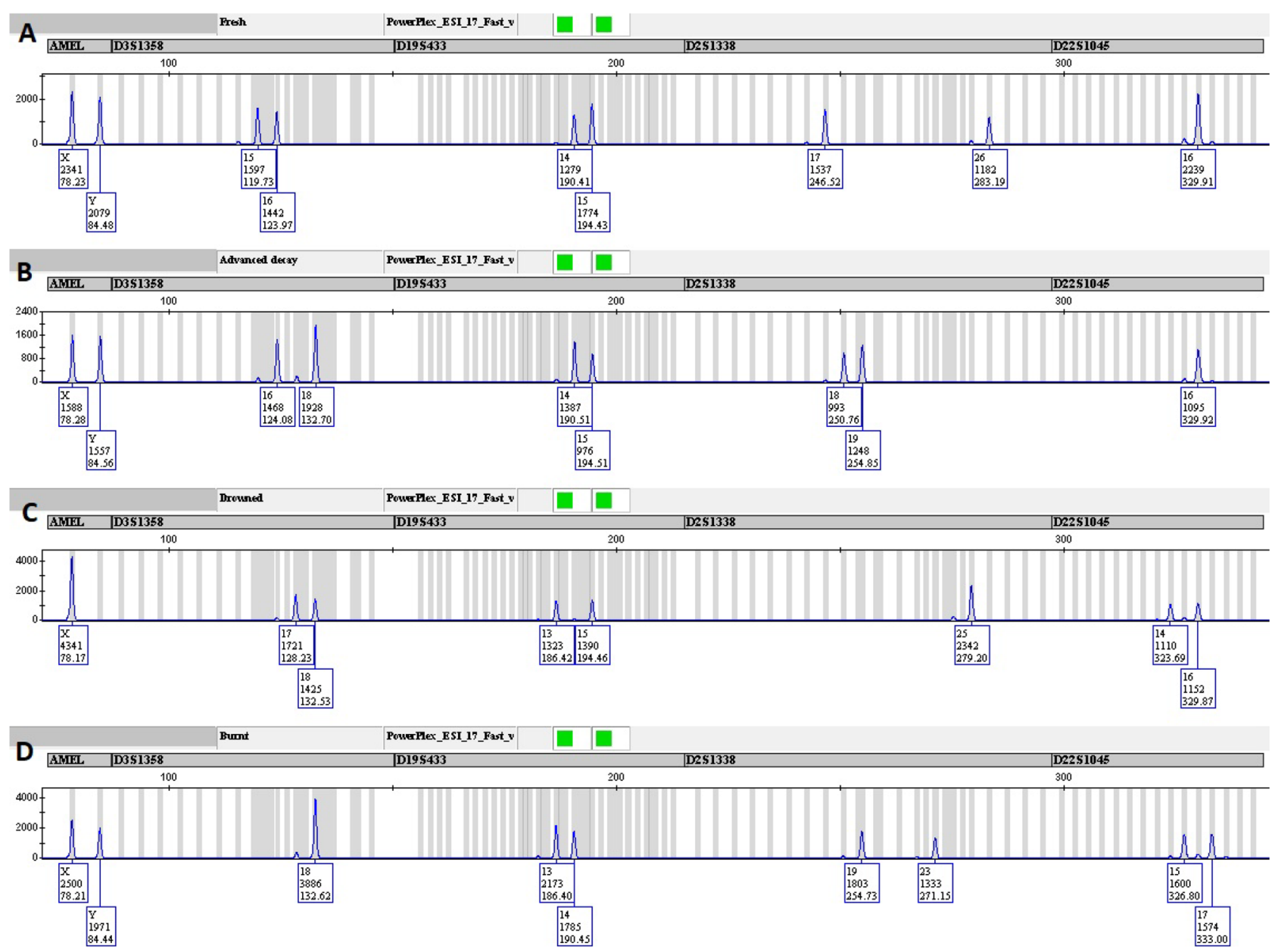

Fig. 1 DNA profiles (blue dye channel, PowerPlex® ESI 17 Fast System) of bodies in the following stages of decomposition: A) fresh B) advanced $\mathbf{C}$ ) burnt $\mathbf{D})$ drowned. The corresponding bodies are marked in Table 1

Authors' contributions $\mathrm{J}$ Becker and $\mathrm{P}$ Boehme contributed equally to the conception and design of the study, acquisition of data, or analysis and interpretation of data. NS Mahlke and S Ritz-Timme were responsible for the medical evaluation of the samples. J Becker wrote the manuscript. All authors contributed equally to the revision of the article critically for important intellectual content and approved the final version before its submission.

Funding Open Access funding enabled and organized by Projekt DEAL.

\section{Declarations}

Ethics declarations All procedures performed in studies involving human tissue were in accordance with the ethical standards of the institutional and/or national research committee and with the 1964 Helsinki declaration.
Conflict of interest Authors and corresponding author does not have conflict of interests in writing and submitting for publication the manuscript.

Open Access This article is licensed under a Creative Commons Attribution 4.0 International License, which permits use, sharing, adaptation, distribution and reproduction in any medium or format, as long as you give appropriate credit to the original author(s) and the source, provide a link to the Creative Commons licence, and indicate if changes were made. The images or other third party material in this article are included in the article's Creative Commons licence, unless indicated otherwise in a credit line to the material. If material is not included in the article's Creative Commons licence and your intended use is not permitted by statutory regulation or exceeds the permitted use, you will need to obtain permission directly from the copyright holder. To view a copy of this licence, visit http://creativecommons.org/licenses/by/4.0/. 


\section{References}

1. Alvarez-Cubero MJ, Saiz M, Martinez-Gonzalez LJ, et al. Genetic identification of missing persons: DNA analysis of human remains and compromised samples. Pathobiology. 2012;79:228-38.

2. Goodwin WH. The use of forensic DNA analysis in humanitarian forensic action: The development of a set of international standards. Forensic Sci Int. 2017;278:221-7.

3. Watherston J, McNevin D, Gahan ME, et al. Current and emerging tools for the recovery of genetic information from post mortem samples: New directions for disaster victim identification. Forensic Sci Int Genet. 2018;37:270-82.

4. Butler JM. Genetics and genomics of core short tandem repeat loci used in human identity testing. J Forensic Sci. 2006;51:253-65.

5. Ottens R, Taylor D, Abarno D, et al. Successful direct amplification of nuclear markers from a single hair follicle. Forensic Sci Med Pathol. 2013;9:238-43.

6. Allouche M, Hamdoum M, Mangin P, et al. Genetic identification of decomposed cadavers using nails as DNA source. Forensic Sci Int Genet. 2008;3:46-9.

7. Raimann PE, Picanço JB, Silva DSBS, et al. Procedures to recover DNA from pre-molar and molar teeth of decomposed cadavers with different post-mortem intervals. Arch Oral Biol. 2012;57:1459-66.

8. Schwark T, Heinrich A, Wurmb-Schwark N. Genetic identification of highly putrefied bodies using DNA from soft tissues. Int J Legal Med. 2011;125:891-4.

9. Sato Y, Motani H, Inoue H, et al. Multiplex STR typing of aortic tissues from unidentified cadavers. Leg Med (Tokyo). 2009;11(Suppl 1):S455-7.

10. Courts C, Sauer E, Hofmann Y, et al. Assessment of STR typing success rate in soft tissues from putrefied bodies based on a quantitative grading system for putrefaction. J Forensic Sci. 2015;60:1016-21.

11. Hoff-Olsen P, Jacobsen S, Mevåg B, et al. Microsatellite stability in human post-mortem tissues. Forensic Sci Int. 2001;119:273-8.

12. van den Berge $M$, Wiskerke D, Gerretsen RRR, et al. DNA and RNA profiling of excavated human remains with varying postmortem intervals. Int J Legal Med. 2016;130:1471-80.

13. Latham KE, Miller JJ. DNA recovery and analysis from skeletal material in modern forensic contexts. Forensic Sci Res. 2019;4:51-9.

14. Samsuwan J, Somboonchokepisal T, Akaraputtiporn T, et al. A method for extracting DNA from hard tissues for use in forensic identification. Biomed Rep. 2018;9:433-8.

15. Palomo-Díez S, Martínez-Labarga C, Gomes C, et al. Comparison of two different DNA extraction methodologies for critical bone or teeth samples. Forensic Sci Int Genet. 2017;6:e359-61.
16. Jakubowska J, Maciejewska A, Pawłowski R. Comparison of three methods of DNA extraction from human bones with different degrees of degradation. Int J Legal Med. 2012;126:173-8.

17. Roeper A, Reichert W, Mattern R. The Achilles tendon as a DNA source for STR typing of highly decayed corpses. Forensic Sci Int. 2007;173:103-6.

18. Trindade-Filho A, Mendes C, Ferreira S, et al. DNA obtained from decomposed corpses cartilage: A comparison with skeleton muscle source. Forensic Sci Int Genet. 2008;1:459-61.

19. Brinkmann B, Madea B, editors. Handbuch gerichtliche medizin. Berlin: Springer; 2004.

20. Madea B. Estimation of the time since death. 3rd ed. Boca Raton: CRC Press; 2015.

21. Agostini V, Gino S, Inturri S, et al. "Unusual" tissues and sample collection strategies on exhumed bodies. Forensic Sci Int Genet. 2019;7:169-71.

22. Whatley BR, Wen X. Intervertebral disc (IVD): Structure, degeneration, repair and regeneration. Materials Sci Eng. 2012;C 32:61-77.

23. Megyesi MS, Nawrocki SP, Haskell NH. Using accumulated degree-days to estimate the postmortem interval from decomposed human remains. J Forensic Sci. 2005;50:1-9.

24. Bär W, Kratzer A, Mächler M, et al. Postmortem stability of DNA. Forensic Sci Int. 1998;39:59-70.

25. Lindahl T. Instability and decay of the primary structure of DNA. Nature. 1993;362:709-15.

26. Alaeddini R, Walsh SJ, Abbas A. Forensic implications of genetic analyses from degraded DNA-a review. Forensic Sci Int Genet. 2010;4:148-57.

27. Boos N, Weissbach S, Rohrbach H, et al. Classification of agerelated changes in lumbar intervertebral discs: 2002 Volvo Award in basic science. Spine. 2002;27:2631-44.

28. Weidner N, Rice DT. Intervertebral disk material: criteria for determining probable prolapse. Hum Pathol. 1988;19:406-10.

29. Lama P, Claireaux H, Flower L, et al. Physical disruption of intervertebral disc promotes cell clustering and a degenerative phenotype. Cell Death Discov. 2019;5:154.

30. Rolauffs B, Williams JM, Grodzinsky AJ, et al. Distinct horizontal patterns in the spatial organization of superficial zone chondrocytes of human joints. J Struct Biol. 2008;162:335-44.

31. Dash HR, Das S. Microbial degradation of forensic samples of biological origin: potential threat to human DNA typing. Mol Biotechnol. 2018;60:141-53.

Publisher's Note Springer Nature remains neutral with regard to jurisdictional claims in published maps and institutional affiliations. 